\title{
Resource use Efficiency of Agricultural Farms in Mid Hills of Indian North-Western Himalayas
}

\author{
Amit Guleria, A.K. Randev', Kapil Dev' and Pardeep Singh ${ }^{1}$ \\ Punjab Agricultural University, Ludhiana-141 004, India \\ ${ }^{1}$ Dr YS Parmar University of Horticulture and Forestry, Nauni, Solan-172 320, India \\ E-mail: amitguleria1201@gmail.com
}

\begin{abstract}
North-west Himalayas of India has been facing the problems of food and feed shortages and nutritional scarcity during winter months, so watershed has been considered to be an effective approach to raise agricultural productivity, conserve natural resources and reduce poverty particularly in rainfed regions. HP Mid-Himalayan Watershed Development Project - an integrated multi-sectoral watershed development project has been operative in Mid Hills of Himachal Pradesh in 10 districts of the state since October 2005. This study has been carried out in order to determine resource utilization on beneficiary farms and to analyse the problems faced by beneficiaries. The project has helped the beneficiaries for sustainable utilization of land and labour through different land development programmes, workshops, trainings and exposure visits. Demand for labour required for irrigation increased due to increase in irrigation facility through construction of village ponds, makowal structures, masonry dams, water harvesting structures and earthen run off dams on 16.66, 10.00, 6.67, 25.00 and 2.78 percent of the total number of beneficiaries. Inputs such as seed, plant protection and irrigation man-days underutilised, so recommendations from the study have been made to increase their respective marginal value productivities. In spite, of above benefits of the project, the beneficiaries have encountered some major problems viz. stray/wild animal menace (72.38\%), lack of technical knowledge of input use (63.27 $\%$ ) and ineffectiveness of working of gram panchayats (60.56 \%) which in case solved may lead to enhancement of efficiency levels of different resources.
\end{abstract}

Keywords: Watershed, Command area, Input use pattern, Resource use efficiency, Productivity

Agriculture has been playing an important role in overall growth of the Indian economy despite its structural shift towards the services sector during the recent decades. Although share of agriculture in GDP has declined from 51.8 percent in 1950-51 (to 17.8 percent in 2019-20, yet this sector has been a major source of employment for rural workers. North-West Himalayas comprise of states of Himachal Pradesh and Uttarakhand and union territory of Jammu and Kashmir; and Ladhakh with mountainous regions transacted by a number of mountain ranges, rivers and rivulets originating from the region. Its physiography is highly undulating with steep slopes and erodible but fertile soils spread over subtropical, temperate-valleys and high hills, very high hills and cold arid regions. Severe and prolonged winter with sub-zero temperature bringing agriculture to almost standstill, fruit trees shedding their leaves and going under dormant phase and livestock experiencing severe morbidity and mortality. There has been an acute food and feed shortages and nutritional scarcity during winter months. The varied agro-ecological situations ranging from sub-tropical to temperate have been enabling vast scope of production of variety of food-grains, fruits, vegetables, flowers, medicinal and aromatic plants, livestock, animal husbandry and fishery. The region as a whole has been reported to be food deficit in terms of cereals, pulses and oilseed, and the average productivity has been reported to be lower than the national average (Anonymous 2015). However, sufficiency in agricultural production has been considered possible through sustainable utilization of land and labour, high yielding varieties, increasing the cropping intensity, irrigation facility and plant protection measures in the command area of the project. Watershed development has been considered an effective approach to raise agricultural productivity, conserve natural resources and reduce poverty, particularly in the rainfed regions. Several useful studies have been conducted in the past to assess the impact of watershed programmes (Reddy 2000, Mondal et al 2012) with respect to various bio-physical and environmental indicators; and have provided useful insights on the performance of numerous watersheds. The Government of Himachal Pradesh has also launched many watershed development projects financed by national and international donor agencies with a view to rehabilitate the degraded environment and improve the economy of the state (Anonymous 2006). In spite of its economic importance sufficient attention has not been given to increase the gross income of the beneficiaries. Specifically, there has been an 
information gap concerning optimal levels of resource utilization in agricultural farms. This study has been carried out in order to estimate the resource use efficiency of the sampled households and to identify the problems faced by beneficiaries and providing remedial solutions.

\section{MATERIAL AND METHODS}

Selection of the study area: For the present study, three districts namely Solan, Sirmaur and Mandi were selected out of 10 districts covered under Mid Himalayan Watershed Development Project. The three districts selected represents 17 development blocks out of 42 , comprising 40.4 percent of the total command area.

Sampling procedure: Primary data have been obtained through the use of pre-tested structured schedule administered to beneficiaries and non-beneficiaries selected by multistage stratified random sampling. At the first stage, two development blocks from each three selected districts, therefore six blocks comprising of 35.3 percent of the total number of development blocks have been selected. At the second stage, three gram-panchayats from each block, thus 18 gram panchayats have been selected from six blocks. At the third stage, a sample of 10 farmers from each grampanchayat by adopting probability proportion to size method have been selected, thereby a sample of 180 beneficiaries has been selected for the study. Simultaneously, a sample of 90 non-beneficiaries has also been selected from the adjacent villages assumed to be unaffected by the project interventions by adopting probability proportion to size method.
Collection of data: Data was collected on the input used in agricultural farms viz. gross return from major crops, area (bighas), labour (man-days), manure and fertilizer (Rs.), seed (Rs.), plant protection (Rs.) and irrigation labour (mandays). The data have been analysed using descriptive and inferential statistics. Cobb-douglus production function has been selected in conformity with priority economic criteria of the magnitude of the coefficients, signs and significance of the adjusted coefficient of multiple determination $\left(R^{2}\right)$, F-ratio and t-ratio. The simple and linear logarithmic form of the specified Cobb-Douglas function is given as;

$\mathrm{Y}=\mathrm{aX}{ }_{1}^{\mathrm{b} 1} \mathrm{X}_{2}^{\mathrm{b} 2} \mathrm{X}_{3}^{\mathrm{b} 3} \mathrm{X}_{4}^{\mathrm{b} 4} \mathrm{u}$

Where:

$Y=$ Gross return

$\mathrm{X}_{1}, \mathrm{X}_{2}, \mathrm{X}_{3}, \mathrm{X}_{4}, \mathrm{X}_{5}$ and $\mathrm{X}_{6}$ have been area, labour, manure and fertilizer, seed, plant protection and irrigation respectively.

$$
\begin{aligned}
& a=\text { intercept } \\
& u=\text { error term }
\end{aligned}
$$

The coefficients are the marginal productivities of the corresponding inputs with respect to output. To ensure maximum profit and efficiency of resource, a farmer must utilize resources at the level where their marginal value product (MVP) is equal to their marginal factor cost (MFC). The efficiency ratio of a resource $(r)$ has been determined by the ratio of MVP of inputs (based on the estimated regression coefficients) and the MFC. The efficiency ratio has been given as;

$$
r=M V P / M F C
$$
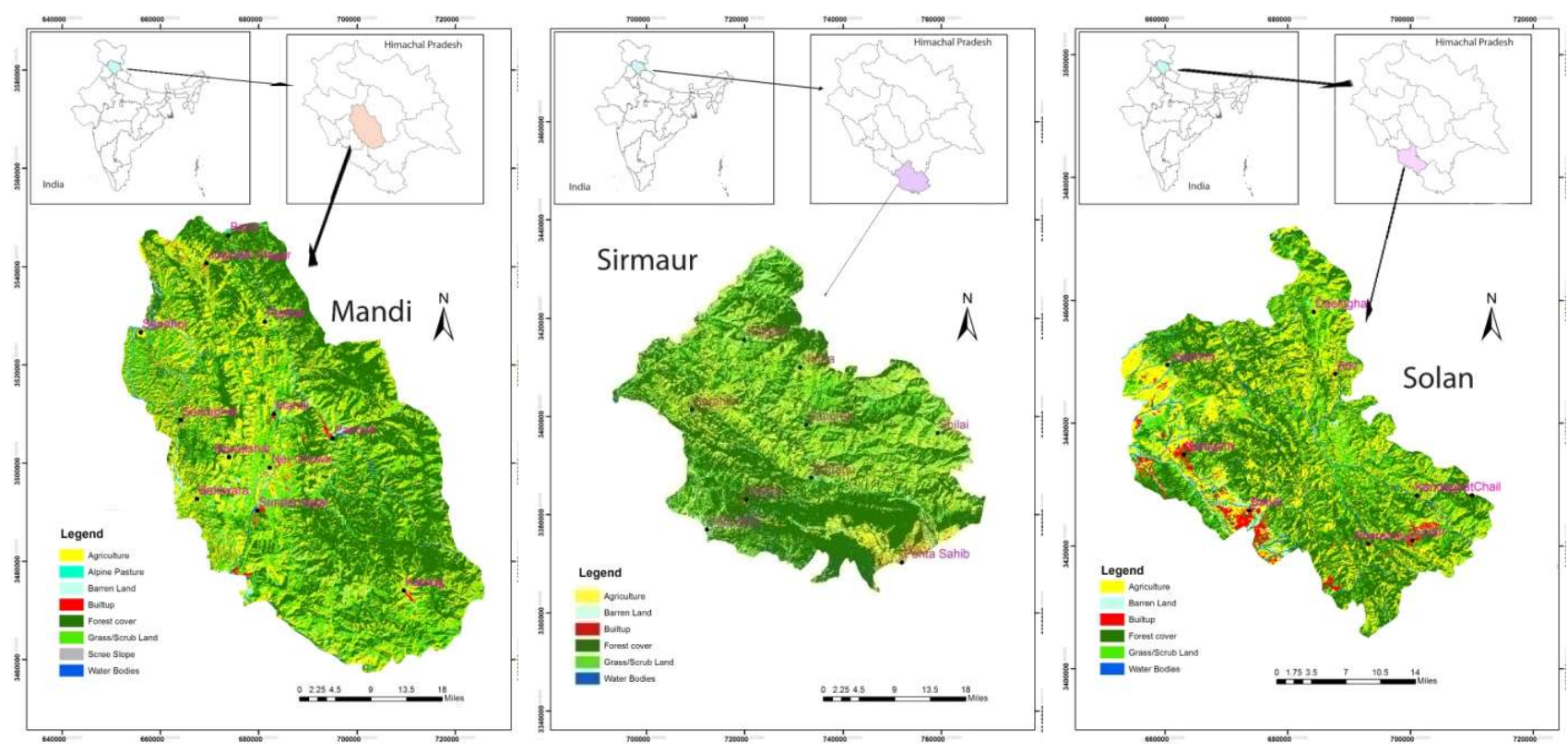

Fig. 1. Location map of the study area 
The decision rule for the efficiency analysis is if:

$r=1$; resource used efficiently

$r>1$; resource was underutilized and increased utilization will increase output.

$r<1$; resource was over utilized and reduction in its usage will lead to maximization of profit.

The absolute value of the percentage change (D) in the MVP of each input used has been calculated as:

$$
D=\left(1-\frac{M I C}{M V P}\right) \times 100
$$

Where, D is the absolute value (Iheanacho et al 2000).

Garrett's ranking technique: The problems encountered by beneficiaries have been analysed using Garrett's ranking technique. The ranks given by respondents have been converted into percent position by using following formula:

$$
\text { Percent position }=\frac{100 \times\left(R_{i j}-0.5\right)}{N_{j}}
$$

Where,

$R_{i j}=$ Rank given to $i^{\text {th }}$ problem by the $j^{\text {th }}$ individual and

$\mathrm{N}_{\mathrm{j}}=$ Number of problems ranked by $\mathrm{j}^{\text {th }}$ individual.

The estimated percent positions have been converted into scores using Garrett's table. The mean score values have been estimated for each factor and have been arranged in the descending order. The constraint with the highest mean value has been considered as the most important one and the other followed that order (Karthick et al 2013).

\section{RESULTS AND DISCUSSION}

Farm specific characteristics: The beneficiary farms in spite of having lesser land holding (1.29 ha) put more land under cultivation and orchards by 7.82 cent and 0.99 percent due to increase in irrigated area by 17.99 percent as compared to non-beneficiary farms. Dev et al (2017) and Kulshrestha et al (2014) also observed hat with the interventions of the project, there has been a significant change in the area of major crops.

Input use pattern: Average operational holding was higher in case of main vegetables grown on beneficiaries farms like tomato $(74.98 \%)$, capsicum $(52.50 \%)$, pea (87.32\%), garlic

Table 1. Farm specific characteristics of the study area

\begin{tabular}{lccc}
\hline Particulars & Beneficiaries & $\begin{array}{c}\text { Non- } \\
\text { beneficiaries }\end{array}$ & Change (\%) \\
\hline Land use & & & -3.73 \\
Total land holding (ha) & 1.29 & 1.34 & 7.82 \\
Cultivated land (\%) & 41.62 & 33.80 & 0.99 \\
Orchard (\%) & 1.65 & 0.66 & -1.04 \\
Forest (\%) & 3.85 & 4.89 & 17.99 \\
Irrigated area (\%) & 28.00 & 10.01 & \\
\hline
\end{tabular}

(75.05 \%) and ginger (99.14\%) as compared to nonbeneficiary farms (Table 2). The scientific use of land promoting higher value vegetables crops, due to increase in land development programme (4.44\%) and irrigation facility, through construction of village ponds, Makowal structures, masonry dams, water harvesting structure, and earthen run off dams. The area wheat and vegetable crops have increased by 5.88 and 53.42 percent, respectively (Kushwah et al 2016, Ankita et al 2021). Segar et al (2008) has observed that area under maize increased by 4.43 percent due to project interventions among tribals of Chhattisgarh. The strength of active workforce (between ages of 14 to 65 years) has been considered to be directly proportional to the use of resource structure available on agricultural farms. The average utilization of labour has found to be lower in case of main vegetables grown on beneficiaries farms ranges between 9.91 and 3.56 percent as compared to nonbeneficiary farms. This significant decrease in labour force in farming activity, was due to increase in the technical efficiency through workshops (28.89\%), trainings (19.44\%) and exposure visits (12.22 \%). Project Interventions has also helped in creation of diverse source of non-farm activities such as knitting (26.67\%), swing (6.67\%), khadi (3.89\%), cutting and tailoring (3.33\%) and coal making through pine needles $(2.78 \%)$. These project interventions decreasing the disguised unemployment on beneficiary farms and to increase the marginal productivity of labour.

Expenditure on manure and fertilizers has been evaluated by multiplying the physical quantities of different manures and fertilizers used on the farms by their respective prices. The per hectare utilization of manure and fertilizers for beneficiary farms was lower for tomato, capsicum, pea, cauliflower, beans and garlic by 0.96 to 6.28 percent, respectively as compared to non-beneficiary farms. This significant decrease in the utilization of fertilizer has been due to assistance provided for construction of vermi compost pit, distribution of biozyme fertilizers and azolla on 22.22, 11.11 and 5.56 percent of total number of beneficiary farms, respectively, which have made the beneficiaries selfdependent for preparation of fertilizers at lower cost than nonbeneficiary farms. Different livestock improvement programmes like, manger construction on 30.56 percent beneficiary farms, supply of chaff cutter to 33.33 percent beneficiary farms and distribution of goats and poultry birds to 5.56 percent (each) beneficiary farms; dissemination of technology on farm fodder cultivation and crop residue treatment to 2.78 percent (each) and health cover and breeding methods (e.g. artificial insemination) to 5.56 percent of total number of beneficiary farms; along-with up-gradation of livestock management skill through veterinary camps and 
breeding centres to 3.33 percent (each) have led to overall improvement in the livestock sector and also increase in the supply of manures to be used in the beneficiaries farms. Utilization of seed was lower in case of main vegetables grown on beneficiaries farms by 2.29 to 9.58 percent while in cereals it ranged between 7.01 to 10.77 percent (Table 2). This significant decrease in the expenditure of seed has been due to distribution of seed of high yielding varieties to 55.56 percent of the beneficiaries and assistance provided for seed driers $(2.22 \%)$. The per hectare utilization of plant protection measures for beneficiary farms was 0.67 to 8.76 percent lower as compared to non-beneficiary farms (Table 2). This significant decrease in the expenditure of plant protection has been due to workshops (28.89\%), followed by trainings and exposure visits (organized by the project and distribution of spray pumps.
The number of labour required for irrigation for main vegetables like tomato, capsicum, pea, cauliflower, beans, garlic and ginger on per hectare basis has been 15.00 and $12.52,3.76$ and $3.42,3.27$ and 2, 13.21 and $12.17,8.30$ and $6.69,7.38$ and 6.73 and 7.95 and 6.38 man-days, on beneficiary and non-beneficiary farms, respectively (Table 2 ). Increase in the irrigation facility on beneficiary farms through project due to construction of village ponds, makowal structures, masonry dams, water harvesting structure and earthen run off dams on $16.66,10.00,6.67,25.00$ and 2.78 percent respectively of the total beneficiary farms along with emphasis given to roof rain harvesting, rejuvenation of village ponds, tanks and land development programme on $11.11,1.67,14.44$ and 4.44 percent of total number of beneficiary farms have led to increase in number of man-days required for irrigating on beneficiary farms compared to non-beneficiary farms.

Table 2. Input use pattern on beneficiary and non-beneficiary farms in case of major crops

\begin{tabular}{|c|c|c|c|c|c|c|c|c|}
\hline Crops & & Percent & $\begin{array}{c}\text { Area } \\
\text { (Big ha) }\end{array}$ & $\begin{array}{l}\text { Labour } \\
\left(\mathrm{MD} \mathrm{ha}^{-1}\right)\end{array}$ & $\begin{array}{c}\text { Manure + Fertilizer } \\
\left(\text { Rs. ha }{ }^{-1}\right)\end{array}$ & $\begin{array}{c}\text { Seed } \\
\left(\text { Rs. ha }{ }^{-1}\right)\end{array}$ & $\begin{array}{l}\text { Plant protection } \\
\left(\text { Rs. ha }{ }^{-1}\right)\end{array}$ & $\begin{array}{l}\text { Irrigation } \\
\left(\mathrm{MD} \mathrm{ha}^{-1}\right)\end{array}$ \\
\hline \multirow[t]{3}{*}{ Tomato } & B & 68.89 & 2.79 & 94.45 & 28077.26 & 7089.17 & 15620.94 & 15.00 \\
\hline & NB & 80.00 & 1.60 & 103.53 & 29192.41 & 7255.08 & 15440.20 & 12.52 \\
\hline & & & $(74.98)$ & $(-8.78)$ & $(-3.82)$ & $(-2.29)$ & (1.17) & (19.85) \\
\hline \multirow[t]{3}{*}{ Capsicum } & B & 64.44 & 2.32 & 111.92 & 7371.30 & 7621.79 & 9159.32 & 3.76 \\
\hline & NB & 58.89 & 1.52 & 109.63 & 7443.07 & 7805.19 & 9568.31 & 3.42 \\
\hline & & & $(52.50)$ & $(2.08)$ & $(-0.96)$ & $(-2.35)$ & $(-4.27)$ & $(9.86)$ \\
\hline \multirow[t]{3}{*}{ Pea } & B & 81.11 & 3.00 & 220.80 & 7461.96 & 10159.93 & 3843.89 & 3.27 \\
\hline & NB & 71.11 & 1.60 & 233.17 & 7946.50 & 10690.55 & 4212.96 & 2.78 \\
\hline & & & (87.32) & $(-5.30)$ & $(-6.10)$ & $(-4.96)$ & $(-8.76)$ & (17.59) \\
\hline \multirow[t]{3}{*}{ Cauliflower } & B & 15.56 & 1.22 & 160.07 & 9282.72 & 8683.41 & 9381.02 & 13.21 \\
\hline & NB & 32.22 & 1.35 & 171.66 & 9904.53 & 9602.89 & 9444.71 & 12.17 \\
\hline & & & $(-9.66)$ & $(-6.75)$ & $(-6.28)$ & $(-9.58)$ & $(-0.67)$ & $(8.52)$ \\
\hline \multirow[t]{3}{*}{ Beans } & B & 20.56 & 0.94 & 172.90 & 9753.34 & 14644.84 & 11188.80 & 8.30 \\
\hline & NB & 26.67 & 1.04 & 179.33 & 10290.27 & 15836.82 & 11757.05 & 6.69 \\
\hline & & & $(-9.91)$ & $(-3.58)$ & $(-5.22)$ & $(-7.53)$ & $(-4.83)$ & (23.97) \\
\hline \multirow[t]{3}{*}{ Garlic } & B & 63.89 & 2.13 & 118.34 & 46947.39 & 43867.55 & 21857.39 & 7.38 \\
\hline & NB & 71.11 & 1.22 & 117.00 & 48833.52 & 45471.83 & 22365.36 & 6.73 \\
\hline & & & $(75.05)$ & $(1.15)$ & $(-3.86)$ & $(-3.53)$ & $(-2.27)$ & (9.75) \\
\hline \multirow[t]{3}{*}{ Ginger } & B & 22.22 & 2.27 & 119.20 & 53670.74 & 137420.24 & 24203.78 & 7.95 \\
\hline & NB & 22.22 & 1.14 & 123.60 & 53611.81 & 142232.14 & 25259.22 & 6.38 \\
\hline & & & $(99.14)$ & $(-3.56)$ & $(0.11)$ & $(-3.38)$ & $(-4.18)$ & $(24.55)$ \\
\hline \multirow[t]{3}{*}{ Wheat } & B & 75.00 & 3.15 & 38.96 & 17944.79 & 3475.77 & 290.62 & - \\
\hline & NB & 87.78 & 2.01 & 38.82 & 19148.48 & 3737.66 & 288.33 & \\
\hline & & & $(57.15)$ & $(0.35)$ & $(-6.29)$ & $(-7.01)$ & $(0.79)$ & \\
\hline \multirow[t]{3}{*}{ Maize } & B & 77.78 & 2.28 & 38.90 & 13218.66 & 4097.57 & 281.93 & - \\
\hline & NB & 87.78 & 2.06 & 40.89 & 13895.64 & 4592.33 & 281.81 & \\
\hline & & & $(11.04)$ & $(-4.86)$ & $(-4.87)$ & $(-10.77)$ & $(0.04)$ & \\
\hline
\end{tabular}


Productivity of main crops: Productivity of various important cash crops on agricultural farms has been shown in (Table 3). The maximum yield level has been obtained in tomato (298 and $333 \mathrm{q} / \mathrm{ha}$ ) followed by garlic, cauliflower, ginger, beans, capsicum, pea, maize and wheat, respectively for non-beneficiaries and beneficiaries. Thus, major crops have shown about 7 to 30 percent enhancement in physical productivities levels on beneficiary farms as compared to non-beneficiary farms. The changes in crop productivity levels have been found to be statistically significant on beneficiaries as compared to non-beneficiaries (Table 4). The respondents have observed that enhancement in physical productivities levels was due to creation of water resources, soil conservation structures, assistance for vermi composting, distribution of farm implements and high yielding seeds. Jat et al (2008) and Kushwah et al (2016) have also observed that productivity of different crops increased due to watershed development project interventions.

Resource use efficiency on agricultural farms: The included variables in model were explained 95 percent of variation in main vegetables and cereals for beneficiary and 98.0 percent for non-beneficiary farms (Table 5).

The regression coefficients of area, seed, plant protection chemicals and irrigation was positive, 0.46, 0.36, 0.31 and 0.42 respectively, beneficiary farms, whereas, found to be negative $(-0.27)$ in case of fertilizer. The regression coefficients of area, seed, plant protection chemicals and irrigation have been positive, 0.31, 0.09, 0.54 and 0.29 for non-beneficiary farms. Beneficiaries and nonbeneficiaries have been operating in increasing return to scale have been found to be 1.28 and 1.23 , significant indicating sub optimal use of most of the inputs on both types of farms which need to be increased for achieving higher levels of input efficiency that will further leads to enhanced production level of respective crops grown in the study area (Table. 5). Economic adjustment of resources has been

Table 3. Crop productivity of major crops (in q ha ${ }^{-1}$ )

\begin{tabular}{lcc}
\hline Crops & Beneficiaries & Non-beneficiaries \\
\hline Wheat & 19.96 & 17.45 \\
Maize & 28.8 & 22.14 \\
Tomato & 332.86 & 297.94 \\
Capsicum & 115.99 & 104.13 \\
Beans & 117.37 & 106.44 \\
Ginger & 128.6 & 114.67 \\
Pea & 112.79 & 99.65 \\
Garlic & 185.11 & 171.44 \\
Cauliflower & 179.38 & 167.24 \\
\hline
\end{tabular}

examined with the help of the ratios of marginal value product (MVP) of inputs and their marginal input cost (MIC). The marginal value products for area, seed, plant protection and irrigation was higher than their marginal factor costs implying underutilization of inputs, whereas, the marginal value products for fertilizers applied have found to be lower than their marginal factor cost implying over utilization of the inputs by beneficiaries. The area, seed, plant protection and irrigation inputs have been under-utilized, required 91.04, $85.69,91.43$ and 98.92 percent addition, respectively of these inputs for optimal production to be achieved. Similarly, in non-beneficiaries, all inputs have been found to be underutilized. This optimal use of area, seed, plant protection and irrigation MVP has to be increased by $85.80,34.84$, 94.28 and 97.92 percent, respectively (Table 6).

Table 4. Percent change of crop productivity and its significance between beneficiaries and nonbeneficiaries

\begin{tabular}{lcc}
\hline Crops & Percent change & t value \\
\hline Wheat & 13.64 & $8.68^{\star}$ \\
Maize & 30.08 & $26.23^{*}$ \\
Tomato & 11.72 & $24.22^{*}$ \\
Capsicum & 11.39 & $13.67^{*}$ \\
Ginger & 12.15 & $6.89^{\star}$ \\
Beans & 10.27 & $14.27^{\star}$ \\
Pea & 13.19 & $12.89^{\star}$ \\
Garlic & 7.97 & $12.11^{\star}$ \\
Cauliflower & 7.26 & $5.20^{*}$ \\
\hline
\end{tabular}

${ }^{*} p$ value $<0.01$

Table 5. Regression coefficients on agricultural farms based on main vegetables and cereals

\begin{tabular}{lcc}
\hline Parameters & Beneficiary farms & Non-beneficiary farms \\
\hline Intercept & $3.22^{*}$ & $2.50^{*}$ \\
& $(0.20)$ & $(0.11)$ \\
Area (bigha) & $0.46^{*}$ & $0.31^{*}$ \\
& $(0.07)$ & $(0.07)$ \\
Labour (MD) & - & - \\
Fertilizer (Rs.) & $-0.27^{*}$ & - \\
& $(0.08)$ & \\
Seed (Rs.) & $0.36^{*}$ & $0.09^{* *}$ \\
& $(0.04)$ & $(0.04)$ \\
Plant protection (Rs.) & $0.31^{*}$ & $0.54^{*}$ \\
& $(0.02)$ & $(0.03)$ \\
Irrigation (MD) & $0.42^{*}$ & $0.29^{*}$ \\
& $(0.03)$ & $(0.06)$ \\
Adjusted $\mathrm{R}^{2}$ & $0.95^{*}$ & $0.98^{*}$ \\
F & 736.67 & 972.94 \\
Sbi & $1.28^{*}$ & $1.23^{*}$ \\
\hline${ }^{* *} \mathrm{p}<0.05$ and ${ }^{*} \mathrm{p}<0.1$, Figure under parentheses indicates standard error
\end{tabular}


Problem encountered by beneficiaries: The most significant production problem was stray or wild animal menace $(72.38 \%)$ followed by lack of knowledge about seed treatment (63.27\%). Although, different project interventions have been made for irrigation but lack of irrigation facility has been perceived as production problem by 27.91 percent of beneficiary farms. Karthick et al (2013) has also found the water scarcity as one of the production problem encountered by 39.60 percent of sampled households. Similar type of production problems had also been reported by earlier workers (Sisodia et al 2007, Thomas et al 2009),

The major marketing problems viz. price fluctuations in perishable crops $(76.75 \%)$, inadequate post-harvest technologies (48.31\%) and lack of transport facilities (40.98 $\%$ ) have been faced by beneficiaries. Ineffectiveness of working of gram panchayats in supplying inputs including credit facility and weak advisory and extension services have been reported as a problem by 60.56 and 46.31 percent respectively, of the respondents. Similar results had also been reported by Dev et al (2019). The range of production, marketing and financial problems has been found within about 25 to 77 percent, in case solved (Table 7) within budgetary constraints of the input supplying agencies may lead to enhanced resource use efficiency on agricultural

Table 6. Marginal analysis of input used by beneficiaries and non-beneficiaries

\begin{tabular}{|c|c|c|c|c|c|c|c|c|c|c|}
\hline \multirow[t]{2}{*}{ Inputs } & \multicolumn{5}{|c|}{ Beneficiaries } & \multicolumn{5}{|c|}{ Non-beneficiaries } \\
\hline & $\begin{array}{c}\text { Geometric } \\
\text { mean }\end{array}$ & MVP & MIC & $\begin{array}{c}\text { Efficiency } \\
\text { ratio }(r)\end{array}$ & $\begin{array}{c}\text { MVP } \\
\text { adjustment } \\
\text { required }\end{array}$ & $\begin{array}{c}\text { Geometric } \\
\text { mean }\end{array}$ & MVP & MIC & $\begin{array}{c}\text { Efficiency } \\
\text { ratio }(r)\end{array}$ & $\begin{array}{c}\text { MVP } \\
\text { adjustment } \\
\text { required }\end{array}$ \\
\hline Area & 8.87 & 8927.10 & 800.00 & 11.16 & 91.04 & 6.21 & 5634.03 & 800.00 & 7.04 & 85.80 \\
\hline Labour & 62.07 & - & 300.00 & - & - & 54.56 & - & 300.00 & - & - \\
\hline Fertilizer & 13516.64 & -3.44 & 1.00 & -3.44 & 129.09 & 10650.58 & - & 1.00 & - & - \\
\hline Seed & 8734.68 & 6.99 & 1.00 & 6.99 & 85.69 & 6316.88 & 1.53 & 1.00 & 1.53 & 34.84 \\
\hline Plant protection & 4494.99 & 11.67 & 1.00 & 11.67 & 91.43 & 3431.17 & 17.47 & 1.00 & 17.47 & 94.28 \\
\hline Irrigation & 2.61 & 27823.56 & 300.00 & 92.75 & 98.92 & 2.25 & 14422.69 & 300.00 & 48.08 & 97.92 \\
\hline
\end{tabular}

*Underutilized and ${ }^{* *}$ Overutilized

Table 7. Problem encountered by beneficiaries during implementation of project

\begin{tabular}{|c|c|c|}
\hline Problem & Mean score $(\%)$ & Rank \\
\hline \multicolumn{3}{|l|}{ Production problem } \\
\hline Stray wild animal menace & 72.38 & II \\
\hline Lack of knowledge about seed treatment & 63.27 & III \\
\hline Lack of knowledge about the management of common properties resources & 55.35 & $\mathrm{~V}$ \\
\hline Technology is capital and labour intensive & 54.23 & VI \\
\hline Fragmented holding & 53.61 & VII \\
\hline Lack of coordination among the beneficiaries & 44.79 & $x$ \\
\hline Lack of outside field visits for successful implementation of watershed areas & 42.31 & $\mathrm{XI}$ \\
\hline Lack of irrigation facility & 27.91 & XIV \\
\hline \multicolumn{3}{|l|}{ Marketing Problem } \\
\hline Price fluctuations in perishable crops & 76.75 & I \\
\hline Inadequate post-harvest technologies & 48.31 & VIII \\
\hline Lack of transport facilities & 40.98 & XII \\
\hline Unfavourable climatic conditions & 37.61 & XIII \\
\hline High marketing cost & 25.63 & $\mathrm{XV}$ \\
\hline \multicolumn{3}{|l|}{ Financial Problem } \\
\hline Ineffectiveness of working of gram panchayat & 60.56 & IV \\
\hline Weak advisory and extension services & 46.31 & IX \\
\hline Chi square value & $59.65^{\star}$ & \\
\hline
\end{tabular}


farms in the study area that can further lead enhanced crops/livestock production levels and to overall social welfare.

\section{CONCLUSIONS}

Project interventions have assisted beneficiaries to bring shift to their cropping pattern through high value cash crops and that has brought changes in area under cultivation and decreased the expenditure on various inputs. Resource use efficiency of agricultural farms has shown that inputs such as seed, plant protection and irrigation have more positive and significant influence on resource use efficiency and crops productivities on beneficiary farms as compared to non-beneficiary farms. Crops' productivities on beneficiary farms have been found to be increased within a range of about 7 to 30 percent as compared to non-beneficiary farms, due to increased levels of irrigation infrastructure. The beneficiaries have been found facing major problems like perishable nature of the produce, stray/wild animal menace and ineffectiveness of gram panchayats. The study has suggested to bring in increase in cold storage facility; frame policy for wild animal menace specially monkey; provide good extension services and stream line working of gram panchayats to readily overcome the problems faced by farmers in the study area.

\section{ACKNOWLEDGMENT}

The authors are grateful to Indian Council of Social Science Research, New Delhi for their support in this study.

\section{REFERENCES}

Ankita, Singh P and Guleria A 2021. Value chain analysis of tomato in Himachal Pradesh: A case study of Kullu District. Indian Journal of Ecology 48(2): 411-417.

Anonymous 2006. Report of Agricultural Census 2005-06, Directorate of Land Records, Shimla 21-22.

Anonymous 2015. Statistical outlines of Himachal Pradesh.
Directorate of Economics and Statistics, Government of Himachal Pradesh.

Anonymous 2017. Status of Farmers' Income. Strategies for Accelerated Growth. Doubling Farmers Income - Volume II. Ministry of Agriculture and Farmer Welfare 1-8.

Dev K, Sharma R, Guleria A and Raj D 2017. Impact Analysis of MidHimalayan watershed development project on socio-economic and agricultural status of beneficiary farms in Ani tehsil of Kullu district in Himachal Pradesh. International Journal of Current Microbiology and Applied Sciences 6: 2244-2255.

Dev K, Sharma R and Guleria A 2019. Impact of mid-Himalayan watershed development project on employment, income generation and problems faced by farmer's in Himachal Pradesh. Indian Journal of Ecology 46: 938-942.

Iheanacho AC, Olukosi IO and Ogungbile AO 2000. Economic efficiency of resource use in millet-based cropping systems in Borno State in Nigerian. Journal of Tropical Agriculture 2: 1829.

Karthick V, Alagumani T and Amarnath JS 2013. Resource use efficiency and technical efficiency of turmeric production in Tamil Nadu: A stochastic frontier approach. Agricultural Economics Research Review 26: 109-114.

Kulshrestha A, Raghubanshi BPS, Sen SK, Kulshrestha A and Singh YK 2014. Impact of watershed programme in Madhya Pradesh, India. Indian Journal of Agricultural Science 48: 145-148.

Kushwah S, Mandal SS and Kumari S 2016. Impact of watershed development programme in district Banka, Bihar Journal of Progressive Agriculture 7: 72-75.

Mondal B, Singh A and Jha GK 2012. Impact of watershed development programmes on farm-specific technical efficiency: A study in Bundelkhand region of Madhya Pradesh. Agricultural Economics Research Review 25: 299-308.

Nirmala B 2003. Impact of watershed development programme on socio- economic dimensions of beneficiaries in Ranga Reddy district of Andhra Pradesh. M.Sc. Dissertation, University of Agricultural Sciences, Dharwad, India.

Reddy VR 2000. Sustainable watershed management- Institutional approach. Economic and Political Weekly 35: 3435-3444.

Sengar RS, Singh BB, Bhardwaj N and Singh AK 2008. Impact of NWDPRA on crop productivity among tribals of Chhattisgarh. Indian Research Journal of Extension Education 8: 54-56.

Sisodia SS, Mittal HK and Sharma C 2007. Constraints in adoption of watershed development technologies: A case study in Rajsamand district of Rajasthan. Indian Journal of Soil Conservation 35: 249-251.

Thomas KJ, Babu KS and Thomas EK 2009. Watershed-based development for rural prosperity evidences from Kerala. Agricultural Economics Research Review 22: 407-414. 